\title{
Hepatitis B carrier state produced by a blood transfusion
}

\author{
J NAGINGTON,* TG WREGHITT,* RS TEDDER, $\dagger$ AND DS DANE $\dagger$ \\ From the *Public Health Laboratory, Level 6, Addenbrooke's Hospital, Hills Road, Cambridge CB2 2QW, \\ and the †Department of Virology, Middlesex Hospital Medical School, London WIP 7LD, UK
}

SUMMARY A renal transplant patient was infected by a transfusion of blood from a chronic carrier of hepatitis B and he also became a symptomless carrier. Stored sera enabled detailed retrospective measurement of the rate of decline of passively transferred $\mathrm{HBsAg}$, anti-HBc, and anti-HBe. Active $\mathrm{HBsAg}$ production was detected after two months and anti-HBc after six months; neither $\mathrm{HBe}$ nor anti-HBe was actively produced although there were many $42 \mathrm{~nm} \mathrm{HBV}$ particles in the patient's serum.

The opportunity to measure the antigen and antibody in the serum of a patient from the time of infection by hepatitis $\mathbf{B}$ has rarely been possible because of the long incubation period and the lack of sera taken before and immediately after infection.

Recently we had an unusual opportunity to assay in detail the hepatitis B markers in the serum of a patient before he was infected, the day after he was infected by a blood transfusion, and through the ensuing months to when he became a symptomless carrier.

A 21-year-old male renal transplant patient was readmitted on 14 June 1979 for a surgical procedure. A blood sample was tested for HBsAg by reverse passive haemagglutination (RPH; Hepatest, Wellcome Reagents) and it showed that he had become antigenaemic, titre 1:6400, since his last test on 19 April 1979. His sera had been under surveillance since 28 May 1974 and had invariably been RPH negative.

It was possible to re-examine these sera from him because they had been stored at $-20^{\circ} \mathrm{C}$, and the discovery that a sample taken on 20 February 1979 was positive for core antibody (anti-HBc) by counter migration electrophoresis (CEP), as described by Cohen and Cossart, ${ }^{1}$ led us to consider the probability that one of two units of blood transfused on 19 February 1979 could have been the source of his infection found four months later. Investigation of the stored serum samples showed that a week before transfusion he was negative $(<0.2 \mathrm{ng} / \mathrm{ml})$ for $\mathrm{HBsAg}$ by radioimmunoassay (RIA) and he had no anti-HBc detectable by CEP or by RIA.

Received for publication 21 January 1980
However, on the day after transfusion his serum was positive for $\mathrm{HBsAg}$ by RIA $(10 \mathrm{ng} / \mathrm{ml})$ and for anti-HBc by CEP and RIA. Both blood donors were traced and bled; one of them, a symptomless Greek woman aged 34 years, was found to be HBsAg positive with an RPH titre of 1 in 8 on 11 July 1979, five months after she had donated her blood. Her liver function tests were all normal and she had no history of hepatitis. We had calculated that the levels of HBsAg and anti-HBc in the donation would have been about 10 times greater than those we found in the recipient on the day after transfusion. As these were in fact the levels in the donor's blood five months later (see Table) we concluded that she was a long-term $\mathrm{HBsAg}$ carrier with stable hepatitis B markers. This meant that her blood donation, which had been screened by the recommended RPH method at a 1 in 8 dilution, would have been on the borderline of detection. Both donor and recipient had the ay subtype of HBsAg. The donor was anti-HBe positive by immunodiffusion and by RIA on 11 July 1979; a trace of anti-HBe was detected in the recipient's serum one and six days after transfusion, suggesting that the donor had also been anti-HBe positive five months earlier when she donated blood. HBsAg carriers with anti-HBe have been shown by Alter et al..$^{2}$ to be much less infectious in needle-stick accidents than those with 'e' antigen (HBeAg). Nevertheless their blood may be infectious when given in large amounts, and on two previous occasions we have demonstrated anti-HBe by immunodiffusion and RIA in stored aliquots of HBsAg positive donations which have caused hepatitis B. 
$\mathrm{HBSAg}$ and anti-HBc in donor and recipient

\begin{tabular}{|c|c|c|c|c|c|}
\hline \multirow[t]{2}{*}{ Serum sample } & \multicolumn{2}{|l|}{$H B s A g$} & \multicolumn{2}{|c|}{$A n t i-H B c$} & \multirow{2}{*}{$\begin{array}{l}\text { Anti-HBe } \\
\text { RIA }\end{array}$} \\
\hline & $R I A$ & $\boldsymbol{R P H}$ & $\boldsymbol{R I A}$ & $C E P$ & \\
\hline \multicolumn{6}{|l|}{ Donor } \\
\hline $\begin{array}{l}11 \text { July } 1979 \\
\text { Recipient }\end{array}$ & $120 *$ & $8 \dagger$ & $6100 \ddagger$ & $++t$ & $98 \ddagger$ \\
\hline $\begin{array}{l}4 \text { August } 1977 \\
12 \text { February } 1979\end{array}$ & - & $\begin{array}{l}<8 \\
<8\end{array}$ & - & - & - \\
\hline \multicolumn{6}{|c|}{$\begin{array}{l}\text { Blood transfusion given on } 19 \text { February } 1979 \\
\text { Recipient }\end{array}$} \\
\hline $\begin{array}{l}20 \text { February } 1979 \\
26 \text { February } 1979 \\
22 \text { March } 1979 \\
19 \text { April } 1979 \\
14 \text { June } 1979 \\
21 \text { August } 1979\end{array}$ & $\begin{array}{l}10 \\
4 \\
- \\
0.5 \\
8 \times 10^{4} \\
8 \times 10^{4}\end{array}$ & $\begin{array}{l}<8 \\
<8 \\
<8 \\
<8 \\
6400 \\
6400\end{array}$ & $\begin{array}{c}620 \\
400 \\
68 \\
13 \\
2 \cdot 2 \\
100\end{array}$ & $\begin{array}{l}++ \\
++ \\
- \\
- \\
-\end{array}$ & $\begin{array}{l}9 \cdot 6 \\
3 \cdot 5 \\
- \\
- \\
-\end{array}$ \\
\hline
\end{tabular}

*Nanograms HBsAg per ml calculated by comparison with the $20 \pm 5 \mathrm{ng} / \mathrm{ml}$ positive control used in Ausria II (Abbot Laboratories). †Reciprocal serum titre.

$\ddagger$ Arbitrary units.

Quantitative results of tests for $\mathrm{HBsAg}$, anti-HBc, and anti-HBe are shown in the Table. Passively transferred HBsAg was still detectable one week after transfusion but not after one month. Antigen resulting from virus multiplication in the recipient was only just detectable $(0.5 \mathrm{ng} / \mathrm{ml})$ two months after the transfusion. The anti-HBc detected on the day after transfusion fell steadily for the next two months, halving its value every 11 days, but by the fourth month the rate of decline had slowed, perhaps due to active production of anti-HBc. The short half-life of the passively acquired antibody may have been due to the patient's imperfect renal function. His active immune response to $\mathrm{HBcAg}$, which was unusually poor, may have been adversely affected by the passive immunity and by the immunosuppressive therapy he was receiving.

Two months after he was found to be positive by RPH a further serum from the patient had an unchanged titre of HBsAg. He has developed no symptoms of hepatitis, his alkaline phosphatase and serum bilirubin have remained normal, and it is assumed that he has become a chronic carrier.

It is unusual that, although there are large numbers of $42 \mathrm{~nm}$ HBV particles present in his serum, he is both $\mathrm{HBe}$ and anti-HBe negative by immunodiffusion and RIA.

Two recipients of earlier blood donations have been traced, and both were found to have anti-HBS although neither gave a history suggestive of clinical hepatitis after transfusion.

\section{References}

${ }^{1}$ Cohen BJ, Cossart YE. Application of a screening test for antibody to hepatitis B core antigen. J Clin Pathol 1977;30:709-13.

2 Alter HJ, Seef LB, Kaplan PM et al. Type B hepatitis: the infectivity of blood positive for $e$ antigen and DNA polymerase after accidental needlestick exposure. $N$ Engl J Med 1976;295:909-13.

Requests for reprints to: Dr J Nagington, Public Health Laboratory, Level 6, Addenbrooke's Hospital, Hills Road, Cambridge CB2 2QW, UK. 